\title{
MONITORING HYDROPEROXIDES FORMATION AS A MEASURE OF PREDICTING WALNUT OXIDATIVE STABILITY
}

\author{
H. Hosseini*, M. Ghorbani, A. Sadeghi Mahoonak and Y. Maghsoudlou \\ Dept. Food Science and Technology, New Paradise of Gorgan University of Agricultural Sciences and Natural \\ Resources, Basij Square, 49138-15739, Gorgan. Iran
}

(Received: 2 February 2013; accepted: 22 April 2013)

\begin{abstract}
It is believed that lipids are the most important factor affecting nuts shelf-life. In the present study, an accelerated shelf-life testing by means of elevated temperatures 62,72 , and $82{ }^{\circ} \mathrm{C}$ was conducted to predict the oxidation stability of walnuts over a long-term storage. Peroxide value (PV) was employed to monitor the lipid oxidation progression in the walnuts. A range of 74.01-79.57 $\mathrm{kJ} \mathrm{mol}^{-1} \mathrm{~K}^{-1}$ energy was required for formation of primary oxidation products. The reaction changes followed an apparent first-order kinetic. Formation of hydroperoxides in walnut kernels was found to be a temperature-dependent reaction with $\mathrm{Q}_{10}$ of 2.1. Walnut kernels were also kept in normal condition (temp: $20-30{ }^{\circ} \mathrm{C}$; relative humidity $(\mathrm{RH}): 35-45 \%$ ) for 12 months to validate the shelf-life estimation approach. The results showed that PV could provide a proper estimation for oxidative stability of the walnuts stored in ordinary condition.
\end{abstract}

Keywords: walnuts, accelerated shelf-life, oxidative stability, peroxide value

Walnuts, among other fat-rich nuts, are sensitive to oxidation, which is believed to be the most common mechanism leading to quality deterioration. The level of polyunsaturated fatty acids (PUFA) in walnuts (62 to $75 \%$ of the total fats) has a direct connection with their oxidation sensitivity, which in turn affects the nut storage life. Accelerated shelf-life testing (ASLT) is often used to determinate the shelf-life in foods, pharmaceuticals, cosmetics, and many other industrial products with limited durability (CORRADINI \& PELEG, 2007). The method is based on the fact that the rate of a shelf-life limiting chemical reaction is increased by an elevation in storage temperature. In a study, Arrhenius relationship and linear models were employed in an ASLT for determination of the effect of peanut coatings on their quality and storage life (LeE \& Krochta, 2002). In another study, Arrhenius model was used in an investigation by LAVELLI and GIOvANELLI (2003) for evaluation of oxidative damage during storage of processed tomato products. The model was also used for prediction of corn flour shelf-life stored at $25{ }^{\circ} \mathrm{C}$ (Lopez-Duarte \& Vidal-Quintanar, 2009). The temperature dependence of most of the reactions in foods can be expressed by the Arrhenius model (Roos, 2001). Since the rate of the reaction increases exponentially with absolute temperature (Gordon, 2004), this parameter is usually chosen to accelerate the oxidation process.

The aim of the present study was to apply an ASLT to investigate the changes in peroxide value of nuts via a kinetic approach, and finally to validate the performed model through comparing the predicted values with the results obtained from storing the nuts for real for a 12-month period.

\footnotetext{
* To whom correspondence should be addressed. Phone/fax: +98-915-6481165/+98-171-4420438; e-mail: hosseini_hamed63@yahoo.com
} 


\section{Materials and methods}

\subsection{Materials}

Walnuts (Juglans regia L.) were harvested in September 2010 and their green soft hulls were removed manually. The nuts were dried immediately in the shade at mid natural air flow $\left(26 \pm 1{ }^{\circ} \mathrm{C}\right.$; RH $\left.27-32 \%\right)$ followed by oven drying at $40{ }^{\circ} \mathrm{C}$ till moisture content reached $2.9 \pm 0.2 \%$. Storage experiments were carried out during the period of September 2010 to October 2011. Under normal storage conditions the nuts were placed in polyethylene trays covered with fine plastic mesh. The trays were kept in a cabinet $\left(25 \pm 5^{\circ} \mathrm{C}\right.$; RH $\left.35-45 \%\right)$ for one year. The temperature and RH in the storage cabinet were checked on a daily basis. For accelerated shelf-life conditions the nuts were placed on stainless steel trays and were incubated at three different temperatures $\left(62,72\right.$, and $\left.82{ }^{\circ} \mathrm{C}\right)$ for about 70,40 , and 30 days, respectively.

\subsection{Chemical analysis}

Moisture and oil contents of the walnuts were determined according to the methods of A.O.A.C. (2005). Approximately $50 \mathrm{~g}$ of ground walnut kernels was transferred into a separatory funnel with $200 \mathrm{ml}$ of diethyl ether, agitated for a few minutes and was allowed to equilibrate for $10 \mathrm{~h}$. The solvent was evaporated from the solvent-oil mixture in a rotary vacuum evaporator (IKA, RV05 Basic, Germany) and the extracted oil was used immediately for chemical analyses. The refractive index in the walnut oil was recorded at $25{ }^{\circ} \mathrm{C}$ by refractometer (CETI, Belgium) according to the A.O.C.S. (1998). Peroxide value (PV) was determined by the iodometric method as stated in A.O.C.S. (2003). Thiobarbituric acid (TBARs) value was measured according to the method of colorimetric absorbance at $530 \mathrm{~nm}$ recommended by A.O.C.S. (2009) using a T80 UV/VIS spectrophotometer (PG Instruments, UK). Specific extinction values at 232 and $268 \mathrm{~nm}$ were measured spectrophotometrically to determine conjugated dienes (CDEs) and trienes (CTEs), respectively, based on I.U.P.A.C. protocol (1987) by using iso-octane as solvent.

\subsection{Estimation of the walnut's oxidative stability}

The change in quality index with time $(\mathrm{dA} / \mathrm{dt})$ can usually be represented by the kinetic equation (1), (Roos, 2001):

$$
-\mathrm{dA} / \mathrm{dt}=\mathrm{kA}^{\mathrm{n}}
$$

where $\mathrm{k}$ is a rate constant; $\mathrm{A}$ is a quality value; $\mathrm{n}$ is a power factor called reaction order. Therefore, the shelf-life (t) of food is inversely proportional to the rate constant (Eq. (2)), after integrating the Eq. (1):

$$
t=\left(A_{o}-A_{e}\right) / k
$$

where $\mathrm{A}_{\mathrm{o}}$ is the initial quality value, $\mathrm{A}_{\mathrm{e}}$ corresponds to the quality value at the end of shelf-life and $t$ is the shelf-life in days, months, years, etc. The Arrhenius equation (Eq. 3) was used for prediction of the nuts oxidation rate constant under normal storage conditions.

$$
\mathrm{k}=\mathrm{k}_{\mathrm{o}} \times \mathrm{e}^{(-\mathrm{Ea} / \mathrm{RT})}
$$

where $\mathrm{k}_{\mathrm{o}}$ is a pre-exponential factor; $\mathrm{E}_{\mathrm{a}}$ is an activation energy in $\mathrm{kJ} \mathrm{mol}^{-1} \mathrm{~K}^{-1}$; $\mathrm{R}$ is the gas universal constant and equals to $8.318 \mathrm{~kJ} \mathrm{~mol}^{-1} \mathrm{~K}^{-1}$; $\mathrm{T}$ is absolute temperature in Kelvin 
scale $\left(273+{ }^{\circ} \mathrm{C}\right)$. The $\mathrm{Q}_{10}$, which also relates to the reaction rate with temperature (LABUZA \& Riвон, 1982), was defined as follows:

$$
\ln \mathrm{Q}_{10}=10 \mathrm{~b}
$$

where $\mathrm{b}$ is the slope of the shelf-life curve ( $\mathrm{Ln} \mathrm{k}$ versus temperature in ${ }^{\circ} \mathrm{C}$ ).

\subsection{Statistical analysis}

All experiments were carried out in triplicates. Significant differences were statistically determined using analysis of variance (ANOVA). The means of the replicates were compared by the least significant difference (LSD) multiple range test by statistical software (JMP 6 for windows). Differences among sample means were reported to be significant when $\mathrm{P}<0.05$.

\section{Results and discussion}

\subsection{Physicochemical properties of walnuts}

The moisture content of the fresh walnut kernels, immediately after drying in shade, was $2.9 \pm 0.2 \%$ and the crude oil content was $68.62 \pm 2 \%$ based on wet matter. The refractive index at $25{ }^{\circ} \mathrm{C}$ and peroxide value (PV) in meq $\mathrm{O}_{2} \mathrm{~kg}^{-1}$, TBARs value, and extinction coefficient $(1 \%, 1 \mathrm{~cm})$ values for conjugated dienes and trienes in fresh walnut oil were determined $1.4733 \pm 0.0004,0.3 \pm 0.01,0.036 \pm 0.001,1.099 \pm 0.008$, and $0.1125 \pm 0.003$, respectively. The moisture contents of the whole walnuts and walnut kernels stored at room temperature, after equilibrium, were determined $3.028 \%$ and $2.97 \%$, respectively, and the figures did not fluctuate significantly during the one year period. The temperature of the nut's storage room fluctuated between $20.69 \pm 0.58{ }^{\circ} \mathrm{C}$ to $22.99 \pm 1.69{ }^{\circ} \mathrm{C}$ during the first 7 months, and from $28.19 \pm 2.68{ }^{\circ} \mathrm{C}$ to $30.04 \pm 1.57{ }^{\circ} \mathrm{C}$ during the last 4 months of the storage period. Based on temperature records, no significant changes were observed during both specified warmer and colder periods. Therefore, for convenience and to avoid complication, $20.88{ }^{\circ} \mathrm{C}$ was considered as an average temperature for the colder period of commencing 240 days and $29.92{ }^{\circ} \mathrm{C}$ for the last warmer period of 120 days.

\subsection{Oxidative stability of the nuts}

Oxidative stability of walnuts was considered as the time required for the nut's peroxide value to reach to 2 meq $\mathrm{O}_{2} \mathrm{~kg}^{-1}$ oil. Different researchers reported a range of values from 1 to 3 meq $\mathrm{O}_{2} \mathrm{~kg}^{-1}$ oil for acceptable quality of walnuts (BurAnsompoB et al., 2003) and other foods (LOPEZ-DuARTE \& VidAL-QuintanAR, 2009). Table 1 shows the oxidative stability (as number of days required for the nut's PV to reach to 2 meq $\mathrm{O}_{2} \mathrm{~kg}^{-1}$ ) of the whole walnuts and walnut kernels stored at 62,72 , and $82^{\circ} \mathrm{C}$, along with the values of CDEs, CTEs, and TBARs for the same nuts when their PV reached to 2 meq $\mathrm{O}_{2} \mathrm{~kg}^{-1}$. As can be seen from Table 1, nut stability decreased significantly $(\mathrm{P}<0.05)$ with an increase in the storage temperature. Moreover, it can obviously be noticed that the nut shells protected the kernels from oxidation at the lower range of accelerated conditions (i.e. 8 days with shells versus 4 days without shells at $\left.62{ }^{\circ} \mathrm{C}\right)$. The oxidation rate $(\mathrm{k})$ of the oils extracted from the whole walnuts and walnut kernels kept under accelerated conditions were determined by plotting the levels of PV against storage time (days). The PV of the nuts steadily increased (Fig. 1) up to the point where the rates of oxidation were changed suddenly. It exhibited a typical behaviour of 
oxidation, which consists of a rapid rising of the oxidation rate followed by a slower rate during storage of the nuts at higher temperatures (the last point at each curve of hydroperoxides formation at different temperatures is the time corresponding to rapid increase of oxidation rate that is not shown in Fig. 1). The first slopes were considered as the rate constant of hydroperoxides formation $\left(\mathrm{k}_{\mathrm{pv}}\right)$ for the nut samples during storage at higher temperatures. Figure 1 shows a rise in PV at higher temperatures over time $\left(\mathrm{R}^{2}>0.93\right)$. The characteristics of the curves in Fig. 1 are presented in Table 2. It obviously shows that the hydroperoxides formation was significantly $(\mathrm{P}<0.05)$ dependent on the temperature and the presence of the shells on the walnuts. Since the oxidation rate at high oxygen partial pressures in a walnut kernel without shell is independent from the oxygen concentration, and it is proportional to the oxygen concentration at low oxygen partial pressures (СHOE \& MiN, 2006), it can be concluded that the shells acted as strong barriers to oxygen and other oxidizing agents. Consequently, the slopes in the PV curves versus time (days) were sharper for walnut kernels than those for whole walnuts at every temperature $\left(62,72\right.$, and $\left.82{ }^{\circ} \mathrm{C}\right)$.

Table 1. Oxidative stability of whole walnuts and walnut kernels stored at higher temperatures $\left(62,72\right.$, and $\left.82{ }^{\circ} \mathrm{C}\right)$.

\begin{tabular}{|c|c|c|c|c|c|}
\hline $\mathrm{T}\left({ }^{\circ} \mathrm{C}\right)$ & Walnut state & $\begin{array}{l}\text { Time required for } \\
\mathrm{PV} \text { to reach to } 2 \\
\text { meq } \mathrm{O}_{2} / \mathrm{kg} \text { (day) }\end{array}$ & $\begin{array}{c}\text { CDEs value at } \\
P V=2\end{array}$ & $\begin{array}{c}\text { CTEs value at } \\
\text { PV }=2\end{array}$ & $\begin{array}{c}\text { TBARs value at } \\
P V=2\end{array}$ \\
\hline \multirow{2}{*}{62} & Whole walnuts & $8.1 \pm 0.99^{\mathrm{a}}$ & $1.739 \pm 0.051^{\mathrm{ac}}$ & $0.287 \pm 0.027^{\mathrm{bd}}$ & $0.061 \pm 0.002^{\mathrm{a}}$ \\
\hline & Walnut kernels & $3.9 \pm 0.68^{\mathrm{bc}}$ & $1.483 \pm 0.102^{\mathrm{d}}$ & $0.27 \pm 0.027^{\mathrm{cd}}$ & $0.061 \pm 0.004^{\mathrm{a}}$ \\
\hline \multirow{2}{*}{72} & Whole walnuts & $4.4 \pm 0.18^{\mathrm{b}}$ & $1.605 \pm 0.087^{\mathrm{bcd}}$ & $0.284 \pm 0.014^{\mathrm{bc}}$ & $0.067 \pm 0.004^{\mathrm{a}}$ \\
\hline & Walnut kernels & $2.7 \pm 0.21^{\mathrm{cd}}$ & $1.666 \pm 0.048^{\mathrm{ab}}$ & $0.306 \pm 0.029^{\mathrm{abc}}$ & $0.066 \pm 0.004^{\mathrm{a}}$ \\
\hline \multirow{2}{*}{82} & Whole walnuts & $2.3 \pm 0.21^{\mathrm{cd}}$ & $1.753 \pm 0.048^{\mathrm{ab}}$ & $0.36 \pm 0.004^{\mathrm{a}}$ & $0.071 \pm 0.005^{\mathrm{a}}$ \\
\hline & Walnut kernels & $1.5 \pm 0.19^{\mathrm{d}}$ & $1.824 \pm 0.098^{\mathrm{a}}$ & $0.333 \pm 0.02^{\mathrm{ab}}$ & $0.07 \pm 0.002^{\mathrm{a}}$ \\
\hline \multicolumn{2}{|c|}{$P$ value $(\alpha=0.05)(T \times$ shell $)$} & 0.0002 & 0.001 & 0.135 & 0.9148 \\
\hline \multicolumn{2}{|c|}{ P value $(\alpha=0.05)(T)$} & $<0.001$ & 0.002 & 0.4 & 0.003 \\
\hline \multicolumn{2}{|c|}{$\mathrm{P}$ value $(\alpha=0.05)$ (shell) } & $<0.001$ & 0.22 & 0.0004 & 0.71 \\
\hline
\end{tabular}

Values in vertical columns with different letters are significantly different $(\mathrm{P}<0.05)$.

Table 2. Regression equations for formation of hydroperoxides during oil oxidation of whole walnuts and walnut kernels stored at 62,72 , and $82{ }^{\circ} \mathrm{C}$.

\begin{tabular}{lcccccc}
\hline $\mathrm{T}\left({ }^{\circ} \mathrm{C}\right)$ & Walnut form & Regression equation & $\begin{array}{c}\mathrm{K}_{\mathrm{PV}} \\
\text { day }\end{array}$ & $\begin{array}{c}\text { Temperature } \\
\text { effect } \\
\text { on } \mathrm{K}_{\mathrm{PV}}\end{array}$ & $\begin{array}{c}\text { Shell effect } \\
\text { on } \mathrm{K}_{\mathrm{PV}}\end{array}$ & $\mathrm{R}^{2}$ \\
\hline 62 & Whole walnuts & $\mathrm{y}=0.2405 \mathrm{x}+0.0369$ & $0.2405^{\mathrm{f}}$ & $0.2691^{\mathrm{c}}$ & $0.6636^{\mathrm{b}}$ & 0.94 \\
& Walnut kernels & $\mathrm{y}=0.2976 \mathrm{x}+0.8489$ & $0.2976^{\mathrm{e}}$ & & $0.7575^{\mathrm{a}}$ & 0.98 \\
$72 \quad$ Whole walnuts & $\mathrm{y}=0.5473 \mathrm{x}-0.4111$ & $0.5473^{\mathrm{d}}$ & $0.5961^{\mathrm{b}}$ & $0.6636^{\mathrm{b}}$ & 0.93 \\
& Walnut kernels & $\mathrm{y}=0.6448 \mathrm{x}+0.2293$ & $0.6448^{\mathrm{c}}$ & & $0.7575^{\mathrm{a}}$ & 0.97 \\
& Whole walnuts & $\mathrm{y}=1.2031 \mathrm{x}-0.7713$ & $1.2031^{\mathrm{b}}$ & $1.2667^{\mathrm{a}}$ & $0.6636^{\mathrm{b}}$ & 0.96 \\
& Walnut kernels & $\mathrm{y}=1.3302 \mathrm{x}+0.0153$ & $1.3302^{\mathrm{a}}$ & & $0.7575^{\mathrm{a}}$ & 0.97 \\
& & & $<0.0007$ & $<0.0001$ & $<0.0001$ & \\
\hline
\end{tabular}

Values in vertical columns with different letters are significantly different $(\mathrm{P}<0.05)$. 


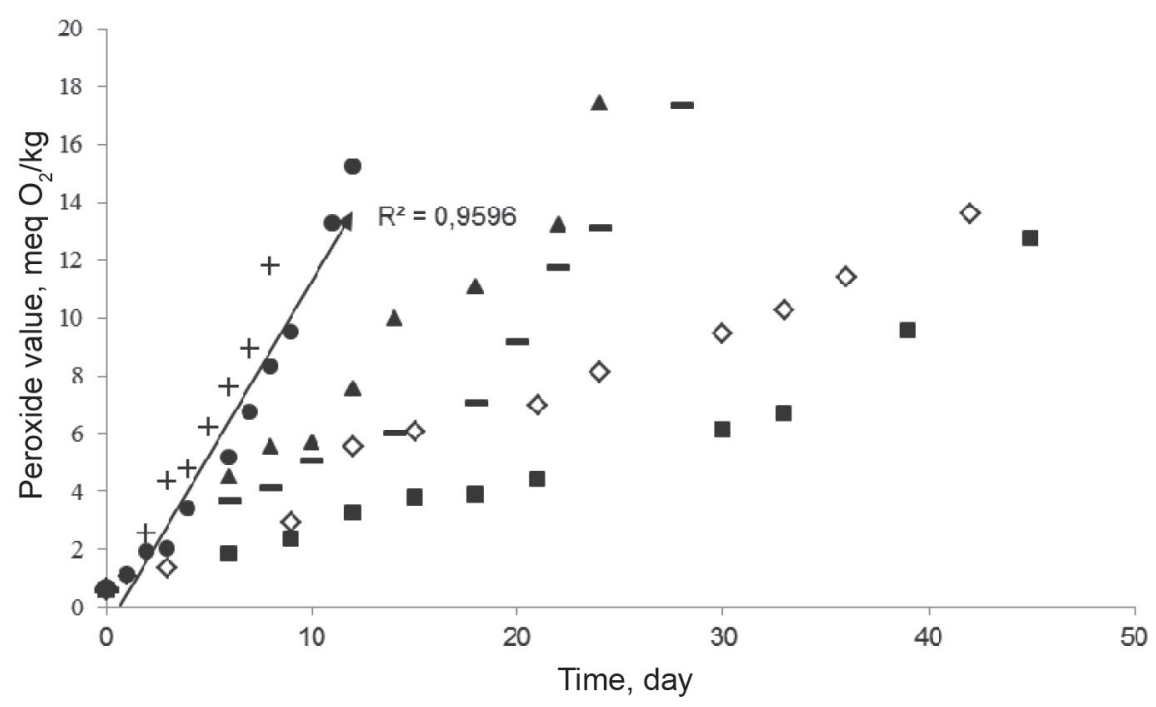

Fig.1. Changes in peroxide value of the oils extracted from the whole walnuts stored at $62(\bullet), 72(-)$ and $82{ }^{\circ} \mathrm{C}(\bullet)$ and walnut kernels stored at $62(\diamond), 72(\boldsymbol{\Delta})$ and $82{ }^{\circ} \mathrm{C}(+)$

\subsection{Predicting the shelf-life of nuts stored under normal conditions}

To extrapolate the $\mathrm{k}_{\mathrm{pV}}$ (1/day) for nuts stored under normal conditions $\left(20.88\right.$ and $\left.29.92{ }^{\circ} \mathrm{C}\right)$, a curve of $\ln \mathrm{k}_{\mathrm{PV}}$ (1/day) of the nuts stored at 62,72 , and $82{ }^{\circ} \mathrm{C}$ was plotted vs $1 / \mathrm{T}\left({ }^{\circ} \mathrm{K}\right)$ with $\mathrm{R}^{2}=0.95-1$ (based on Table 3) as shown in Fig. 2. Properties of Arrhenius plots, including shelf-life equations, $\mathrm{Q}_{10}$, and activation energy $\left(\mathrm{E}_{\mathrm{a}}\right)$ for peroxide value in nuts stored at high temperatures, are presented in Table $3 . \mathrm{Q}_{10}$ and activation energy in $\mathrm{kJ} \mathrm{mol}^{-1} \mathrm{~K}^{-1}$ is considered as a measure of the sensitivity of the reactions to temperature (BELL, 2007). According to Table 3, the amount of energy required to produce hydroperoxides were calculated based on the slope of the Arrhenius equation $\left(\mathrm{m}=\mathrm{E}_{\mathrm{a}} / \mathrm{RT}\right), \mathrm{Q}_{10}$ and $\mathrm{Eq}$. 4 . In a similar study carried out by Lopez-Duarte and Vidal-Quintanar (2009) values of 40.2-104.6 $\mathrm{kJ} \mathrm{mol}^{-1} \mathrm{~K}^{-1}$ for activation energy and 1.5-2 for $\mathrm{Q}_{10}$ during lipid oxidation of dry cereals and corn masa flour were reported. Likewise, LEE and KROCHTA (2002) used hexanal as a measure for oxidation in peanuts coated with different materials under accelerated storage conditions and reported $\mathrm{Q}_{10}$ values of 1.4-1.68 for the samples tested. The reaction rate constant of oxidation for nuts stored under normal conditions $\left(20.88\right.$ and $29.92{ }^{\circ} \mathrm{C}$; RH $35-45 \%$ ) was extrapolated from the curve regression equations in Fig 2. The extrapolated rates were then placed into Eq. (2) to estimate the nuts shelf-life under normal storage conditions as shown in Table 3. The PV of the oil extracted from the whole walnuts and walnut kernels kept under normal conditions for approximately 240 days (with an average temperature of $20.88^{\circ} \mathrm{C}$ ) were 1.148 and 1.803 meq $\mathrm{O}_{2} \mathrm{~kg}^{-1}$, respectively. The same values of 1.148 and 1.803 were obtained by extrapolation, after 192 and 208 days, respectively. The PVs for the whole walnuts and walnut kernels stored under normal conditions at the end of the storage period, i.e. 360 days of storage, were 2.292 and 3.299 meq $\mathrm{O}_{2} \mathrm{~kg}^{-1}$, respectively (Table 3). The estimated time required to reach these values, as calculated by Eq. (2), was 99 and 84 days, respectively (compared with the 
120 days under normal conditions). In a similar study, MASKAN \& KARATAS (1999) reported the values of $0.00433,0.00607$, and $0.00847 /$ day for rate constant of hydroperoxide formation in pistachios during storage at $20^{\circ} \mathrm{C}, 30{ }^{\circ} \mathrm{C}$ and ambient conditions $\left(20-30{ }^{\circ} \mathrm{C}\right.$; RH: $27-$ $97 \%$ ), respectively. They also found that $34.85 \mathrm{~kJ} \mathrm{~mol}^{-1} \mathrm{~K}^{-1}$ energy was needed for production of hydroperoxides during oxidation development under the above conditions. Moisture content of the nuts (around 3\%) decreased to 1\% after 2-3 days storage under accelerated conditions and remained fixed until the point that PV increased to its peak at higher temperatures. Generally, lipid oxidation is minimum in the water activity $\left(\mathrm{a}_{\mathrm{w}}\right)$ range of 0.2 to 0.35. Moisture sorption isotherms in the walnut kernels and its dependence on temperature have been studied by Togrul and Arslan (2007). They proved that equilibrium moisture contents of the walnut kernels at a constant $a_{w}$ decreased with increase in temperature. DOMINGUEZ and co-workers (2007) showed that the behavior of PV changes in macadamia nuts stored at $\mathrm{a}_{\mathrm{w}}=0.436$ was the same as those stored at $\mathrm{a}_{\mathrm{w}}=0.215$. Consequently, the accuracy of the prediction of the walnut oxidative stability can be explained by two justifications; firstly, the PVs for the estimation of oxidative stability of nuts stored at elevated temperatures were comparable with the PVs of less than 19 meq $\mathrm{O}_{2} / \mathrm{kg}$, thus, there could be a slight error in performing ASLT without controlling aw in the nut's storage chamber in this range of PVs. Secondly, if $\mathrm{a}_{\mathrm{w}}$ was considered constant with a pre-defined $\mathrm{RH}$ for walnuts stored at normal temperature, walnuts would have a lower RH at higher temperatures. According to the latter justification, it is possible to ignore the effect of $a_{w}$ for the estimation of oxidative stability of walnuts with moisture content of about $3 \%$. However, further studies must be conducted to scrutinize the effect of moisture content on the oxidative stability of walnuts at high temperatures.

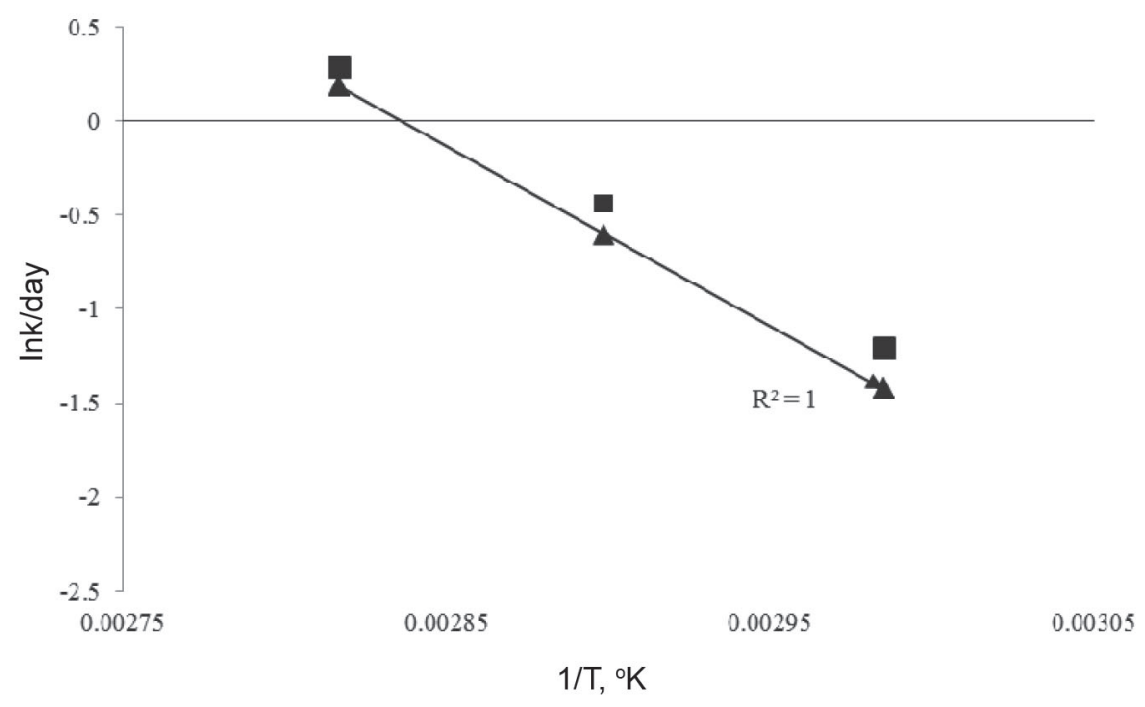

Fig. 2. Arrhenius graph from plotting the natural logarithm of the change rate constant of peroxide values $\left(\ln \mathrm{k}_{\mathrm{pV}}\right)$ for whole walnuts stored at 62,72 and $82{ }^{\circ} \mathrm{C}(\boldsymbol{\Delta})$ and walnut kernels stored at 62,72 and $82{ }^{\circ} \mathrm{C}(\boldsymbol{\bullet})$ versus reciprocal temperature in ${ }^{\circ} \mathrm{K}$. 
Table 3. Arrhenius equations, $\mathrm{R}^{2}, \mathrm{E}_{\mathrm{a}}\left(\mathrm{kJ} \mathrm{mol}^{-1} \mathrm{~K}^{-1}\right)$ and $\mathrm{Q}_{10}$ from accelerated test results and estimated rate constant of peroxide value $\left(\mathrm{k}_{\mathrm{PV}}\right.$ per day) for the nuts stored at normal condition (20.88 and $29.92^{\circ} \mathrm{C}$; RH: $\left.35-45 \%\right)$.

\begin{tabular}{lcccccc}
\hline Samples & Arrhenius equations & $\mathrm{R}^{2}$ & $\mathrm{Ea}\left(\mathrm{kJ} \mathrm{mol}^{-1} \mathrm{~K}^{-1}\right)$ & $\mathrm{Q}_{10}$ & $\begin{array}{c}\mathrm{k}_{\mathrm{pv}} / \text { day at } \\
20.88^{\circ} \mathrm{C}\end{array}$ & $\begin{array}{c}\mathrm{k}_{\mathrm{pv}} / \text { day at } 29.92 \\
{ }^{\circ} \mathrm{C}\end{array}$ \\
\hline $\begin{array}{l}\text { Whole } \\
\text { walnuts }\end{array}$ & $\mathrm{y}=9570.8 \mathrm{x}+27.143$ & 1 & 79.57 & 2.2 & 0.00441 & 0.0116 \\
$\begin{array}{l}\text { Walnut } \\
\text { kernels }\end{array}$ & $\mathrm{y}=8902.4 \mathrm{x}+25.363$ & 1 & 74.01 & 2.1 & 0.00723 & 0.0178 \\
\hline
\end{tabular}

\section{References}

A.O.A.C. (2005): Official method of analysis., 18th ed., No. 40.1.04 and 40.1.05., Association of Official Analytical Chemists, Gaithersburg MD, USA.

A.O.C.S. (1998): Official method of analysis. Cc 7-25. American Oil Chemical Society Washington, DC

A.O.C.S. (2003): Official method of analysis. Cd 8-53. American Oil Chemical Society Washington, DC.

A.O.C.S. (2009): Official method of analysis. Cd 19-90. American Oil Chemical Society Washington, DC.

Bell, L.N. (2007): Moisture effects on food's chemical stability. -In: Barbosa-Canovas, G.V., Fontana, A.J., Schmidt, S.J. \& LabuzA, T.P. (Eds): Water activity in foods: fundamentals and applications. Blackwell Publishing and the Institute of Food Technologists, Washington, pp. 173-198.

Buransompob, A., Tang, J., Mao, R. \& Swanson, B.G. (2003): Rancidity of walnuts and almonds affected by short time heat treatments for insect control. J. Food Process. Pres., 27, 445-464.

Choe, E. \& Min, D.B. (2006): Mechanisms and factors for edible oil oxidation. Comprehensive Rev. Fd Sci. Fd Safety, 5, 169-186.

Corradini M.G. \& Peleg, M. (2007): Shelf-life estimation from accelerated storage data. Trends Fd Sci. Technol., $18,37-47$.

Dominguez, I.L., Azuara, E., Vernon-Carter, E.J. \& Beristain, C.I. (2007): Thermodynamic analysis of the effect of water activity on the stability of macadamia nut. $J$. Fd Eng., 81, 566-571.

Gordon, M.H. (2004): Factors affecting lipid oxidation. -in: STEELE, R. (Ed.): Understanding and measuring the shelf-life of foods. Woodhead Publishing, Cambridge, pp. 128-141.

I.U.P.A.C. (1987):. Evidence of purity and deterioration from ultraviolet spectrophotometry., 7th ed., Method 2.505. -in: Paquot, C. \& Hautfenne, A. (Eds) Standard methods for the analysis of oils, fats and derivatives. Blackwell Scientific, Palo Alto, Calif., pp. 212-213.

LabuZA, T.P. \& Riвон, D. (1982): Theory and application of Arrhenius kinetics to the prediction of nutrient losses in foods. Fd Technol., 36, 66-74.

LaVelli, V. \& Giovanelli, G. (2003): Evaluation of heat and oxidative damage during storage of processed tomato products. II. Study of oxidative damage indices. J Sci. Fd Agric., 83, 966-971.

Lee, S.Y. \& Krochta, J.M. (2002): Accelerated shelf-life testing of whey- protein-coated peanuts analysed by static headspace gas chromatography. J. Agric. Fd Chem., 50, 2022-2028.

Lopez-Duarte, A.L. \& Vidal-Quintanar, R.L. (2009): Oxidation of linoleic acid as a marker for shelf-life of corn flour. Fd Chem., 114, 478-483.

Maskan, M. \& Karatas, S. (1999): Storage stability of whole-split pistachio nuts (Pistachia vera L.) at various conditions. Fd Chem., 66, 227-233.

Roos, Y.H. (2001): Water activity and plasticization. -in: Eskin, N.A.M. \& Robinson, D.S. (Eds) Food shelf-life stability: Chemical, biochemical and microbiological changes. CRC Press, Boca Raton, Florida, pp. 15-48.

Togrul, H. \& ArsLan, N. (2007): Moisture sorption isotherms and thermodynamic properties of walnut kernels. $J$. Stored Prod. Res., 43, 252-264. 